\title{
Comparative Genomic Hybridization of Germ Cell Tumors of the Adult Testis: Confirmation of Karyotypic Findings and Identification of a 12p-Amplicon
}

\author{
M. M. C. Mostert, M. van de Pol, D. Olde Weghuis, \\ R. F. Suijkerbuijk, A. Geurts van Kessel, J. van Echten, \\ J. W. Oosterhuis, and L. H. J. Looijenga
}

\begin{abstract}
Comparative genomic hybridization (CGH) was carried out on 15 primary testicular germ cell tumors (TGCT) of adolescents and adults and two metastatic residual tumors after chemotherapeutic treatment. The results were compared with karyotypic data obtained form the same tumor specimens after direct harvesting of metaphases or short-term in vitro culture. Both techniques revealed that the most consistent abnormality in primary TGCT is gain of $12 p$-sequences. Although in most cases overrepresentation of the complete short arm was observed, CGH revealed a specific amplification of 12p11.1-p12.1 region in two independent primary tumors. In addition, loss of (parts of) chromosome 13 (always involving q31-qter), and gain of (parts of) chromosome 7 (mostly involving q11), (parts of) chromosome 8 , and the $X$ chromosome were detected in more than $25 \%$ of the tumors by this latter technique. Loss of 6q15-q21 in both residual tumors analyzed may suggest a role for this anomaly in acquired resistance to chemotherapeutic treatment.

Overall, the CGH analyses confirmed gains and losses of certain chromosomal regions in TGCT as observed by karyotyping, and thus support their role in the development of these neoplasms. The amplification of a restricted region of $12 p$ in primary TGCT confirms and extends our previous observations and, as such, represents an important step forward in the identification of gene(s) on $12 p$ relevant for the pathogenesis of these tumors.
\end{abstract}

\section{INTRODUCTION}

The most common cancer in the caucasian young adult male population is the germ cell tumor of the testis (TGCT) [1, for review]. Because its incidence is still increasing, and effective treatment in its preinvasive stage is possible [2], understanding of the mechanisms involved in the etiology of this neoplasm may have important implications for the development of early detection strate-

From the Laboratory for Experimental Patho-Oncology, Dr. Daniel den Hoed Cancer Center, University Hospital Rotterdam (M. M. C. M., M. v. d. P., J. W. O., L. H. J. L.); Department of Human Genetics, University Hospital Nijmegen (D. O. W., R. F. S., A. G. v. K.); Department of Medical Genetics, University of Groningen (J. v. E.), The Netherlands.

Correspondence to: Dr. M. M. C. Mostert, Laboratory for Experimental Patho-Oncology, Dr. Daniel den Hoed Cancer Center Groene Hilledijk 301, 3075 EA Rotterdam, The Netherlands.

Received November 30, 1995; accepted January 26, 1996 gies. In spite of its technical limitations in the study of solid tumors in general, karyotyping has been highly informative in the detection of chromosomal aberrations in TGCT [3-5]. In accordance with results of total DNA content analysis [6, 7], TGCT are found to be aneuploid, around the triploid range. Besides consistent over- and underrepresentations of some (parts of) chromosomes, the only recurrent structural abnormality is the isochromosome $12 p$ [i(12p)] [5], first reported in TGCT by Atkin and Baker in 1983 [8]. This anomaly is found less frequently in seminomas (SE), composed of malignant counterparts of early germ cells, than in nonseminomatous TGCT (NS), which are caricatures of early embryonal development composed of embryonal (embryonal carcinoma (EC) and teratoma (TE)) and/or extraembryonal (yolk sac (YS) and choriocarcinoma $(\mathrm{CH})$ ) components $[9,10]$. Fluorescence in situ hybridization (FISH) using region-specific probes showed that also i(12p)-negative TGCT invariably exhibit overrepresentations of $12 \mathrm{p}$-sequences $[11,12]$. Because conventional cytogenetic information is derived from mitotic cells, such data may be biased due to selection of 
subpopulations of cells by the methods of direct harvesting or short-term in vitro culture. This has recently been suggested for SE with respect to the presence of $i(12 p)$ [13]. Also the presence of markers of which, by definition, the chromosomal origin can not be determined, may hamper the identification of certain chromosomal regions important for the development of this cancer.

Comparative genomic hybridization (CGH) allows the detection of DNA copy number changes in relatively small amounts of tumor DNA [14]. Because no metaphase spreads are required $\mathrm{CGH}$ can be applied regardless of mitotic activity, thereby excluding in vivo or in vitro selection. In addition, CGH offers the possibility of revealing regions of amplification or deletion that are not identifiable via karyotyping.

We analyzed a series of 15 primary TGCT (including both SE and NS) and two metastatic residual tumors after chemotherapeutic treatment using both karyotyping and $\mathrm{CGH}$. The metaphase spreads were isolated via direct harvesting of the $S E$ and after short-term in vitro culture of the NS. Similarities and differences in the chromosomal constitution of the various tumor samples as detected by both techniques are evaluated.

\section{MATERIALS AND METHODS}

\section{Patient samples}

Fifteen TGCTs collected from collaborating hospitals in the Western part of the Netherlands were used in this study. The tumors were classified according to the World Health Organization (WHO) recommendations [9], as described [6], and identified as six SE, seven NS, and two combined tumors (CT) [15]. The tumors were surgically removed before the patient was treated with chemotherapy and/or irradiation. In addition, two metastatic residual tumors, one mature TE (2101) and one EC (5695), were studied. Representative parts of tumor component(s) were snap frozen in liquid nitrogen (for DNA isolation) and fixed in $4 \%$ buffered formalin for paraffin embedding (for histological classification).

\section{Slide Preparation and Karyotyping}

Metaphase spreads of SE and NS were prepared according to standard procedures. Briefly, the mitotic cells of the SE were, after mechanical dissociation of the tumor, directly harvested in the presence of Colcemid (Life Technologies, New York, USA). The cells were subsequently swollen in hypotonic $\mathrm{KCl}$ solution and fixed with methanol-acetic acid (3:1). The NS were enzymatically digested using collagenase and cultured in vitro for a few days, after which they were treated as reported before $[16,17]$.

For karyotyping, air-dried preparations were banded using pancreatin (Sigma, St. Louis, USA) as reported [18]. The chromosomal constitutions were described according to the recommendations of the ISCN 1991 [19], and calculated on the basis of a triploid DNA content, to stress the over- and underrepresentations of (parts of) chromosomes relative to the triploid situation. Although the NS were randomly selected, five i(12p)-negative SE were chosen for this survey (see Table 1). Such tumors may be instrumen- tal in the delineation of the critical region of overrepresentation of the short arm of chromosome 12, as was suggested recently through the analysis of a metastasis of a SE [12].

\section{Comparative Genomic Hybridization and Interpretation}

For CGH, metaphase spreads were prepared using standard procedures (see above) from in vitro phytohemagglutinin-stimulated peripheral blood lymphocyte cultures of a healthy male $(46, X Y)$. High molecular weight DNA of the tumor as well as control DNAs (from peripheral blood cells of healthy males), were isolated using standard procedures [20]. CGH was performed as described before [12, 21-23]. To exclude false positive and false negative observations, DNAs obtained from 10 healthy individuals were analyzed as described for the tumors. Regions that showed variations in centromeric and heterochromatic regions, p-arms of acrocentric chromosomes and telomeric regions, were omitted from analysis.

For each hybridization, $400 \mathrm{ng}$ digoxigenin (11-dUTP [Boehringer Mannheim, GR]) labeled tumor DNA and a similar amount of biotinylated (14-dATP [GIBCO-BRL]) control DNA were used. Eighty $\mu \mathrm{g}$ of COT-1 DNA (Life Technologies) was added as competitor DNA to reduce background signal due to repetitive sequences. After 2-4 days of incubation under a coverslip in a moist chamber at $37^{\circ} \mathrm{C}$, the slides were washed according to regular FISH protocols [24]. Visualization of the hybridized DNAs was achieved with fluorescein isothiocyanate (FITC) conjugated sheep-anti-digoxigenin (Boehringer) and pentamethine cyanine dye isothiocyanate (CY3) conjugated avidin (Jacksons ImmunoResearch Laboratories, West Grove, USA). The results were evaluated using a Zeiss Axiophot epifluorescence microscope, equipped with a Photometrics high-performance CH250/A cooled CCD-camera (Photometrics, Tucson, AZ) interfaced onto a Macintosh Quadra 950 computer using the comparative genomic hybridization applications within the Oncor-Image FISH software package (Oncor, Gaithersburg, MD). These applications allow a pseudocolor reproduction of fluorescence ratios of $\mathrm{CY} 3$ (reference DNA) and fluorescein (tumor DNA).

All TGCTs were analyzed assuming no host cell contamination, i.e., instrument setting of $\mathbf{1 0 0} \%$ tumor. Because SE are known to contain variable amounts of infiltrating lymphocytes [9], these were also analyzed assuming $50 \%$ host cells [25]. For each tumor, five metaphase spreads, with similar imbalances on both chromatids, were interpreted according to previously published criteria [22, 23, 26]. Digital analysis allowed representation of the results as fluorescence intensity profiles for each fluorochrome along the chromosome. Photographic images were made using a Tektronics SDXII color dye sublimation printer.

\section{RESULTS}

The cytogenetic data of the primary TGCTs and the residual tumors are summarized in Table 1 as modal representative karyotypes. All showed an aneuploid DNA content around the triploid range with multiple numerical and structural aberrations. The modal number of short and long 
Table 1 Modal representative karyotypes of the testicular germ cell tumors of adolescents and adults (TGCTs), based on a triploid DNA content (the aberrations also detected by a comparative genomic hybridization are underlined)

Histology Case Chromosomal Constitution

Seminoma

4255

1665

5718

5731

7214

2655

Nonseminoma

5116

6537

8007

1862

2871

Combined TGCTs

Seminoma

Seminoma

3284

Residual Tumors
68-76,XXY, add(1)(q12), $+\operatorname{dic}(1 ; 12)(\mathrm{p} 13 ; \mathrm{q} 22),-5,+? \operatorname{del}(6)(\mathrm{q} 21 \mathrm{q} 23),+7,+8,+8,-13,+14,+15,-18$ $+21,-22,+1-7 \operatorname{mar}[\operatorname{cp} 11]$

57-59,X,der(X)del(X)(p22)t(X;12)(q23;q12),-Y,add(1)(q24),+add(1)(p13),-2,dic(3;22)(p11;p11), $\mathrm{i}(3)(\mathrm{p} 10),+\mathrm{i}(3)(\mathrm{q} 10),-4, \operatorname{dic}(4 ; 13)(\mathrm{q} 35 ; \mathrm{p} 12),-5,-7,+8,-9,-10,-11, \operatorname{add}(12)(\mathrm{q} 24.1),+\mathrm{i}(12)(\mathrm{p} 10)$, $-13,-13, \operatorname{dic}(13 ; 19)(\mathrm{p} 11 ; \mathrm{q} 11),-15, \operatorname{der}(15) \mathrm{t}(15 ; 15)(\mathrm{p} 13 ; \mathrm{q} 11),-16,-17,-18, \operatorname{der}(20) \mathrm{t}(1 ; 2 ; 20 ; ?)$ $(\mathrm{q} 25 \mathrm{q} 44 ; \mathrm{q} 32 ; \mathrm{q} 12 ; ?),-21, \operatorname{add}(21)(\mathrm{p} 12), \operatorname{der}(21) \mathrm{t}(21 ; 21)(\mathrm{p} 12 ; \mathrm{q} 11.1), \operatorname{der}(22) \mathrm{t}(7 ; 22)(\mathrm{q} 11 ; \mathrm{p} 12),+\operatorname{mar} 1$ $+\operatorname{mar} 2,+\operatorname{mar} 3,+1-3 \operatorname{mar}[\mathrm{cp} 7]$

69-74,XXY,der(1)t(1;16)(p12;p11.2),add(3)(q24),-4,-5,+del(7)(p12), $+\operatorname{der}(8) \mathrm{t}(8 ; 12)(\mathrm{q} 10 ; \mathrm{p} 11) \mathrm{x} 2$ $-9, \operatorname{add}(9)(q 34), \operatorname{der}(9) \mathrm{t}(3 ; 9)(\mathrm{q} 13 ; \mathrm{p} 24),-11,+12,-13,-15,-17, \operatorname{add}(17)(\mathrm{p} 11.2),-18, \operatorname{add}(18)(\mathrm{q} 22)$, add(19)(p13.2), +21,+21,+21,+22,+der(?)t(?;12)(?;p11),+mar1,+0-2mar[cp10]

$71-82, X X Y,+1,+2, \mathrm{i}(4)(\mathrm{q} 10),-5,+6,+7,+8,+\operatorname{add}(12)(\mathrm{p} 11),-13,+14,+15,+19,-20,+21,+21,+22$, $+\operatorname{mar} 1,+1-6 \operatorname{mar}[\operatorname{cp} 9]$

55-69,XXY, +add(1)(p22),der(2)t(2;mar1)(q37;?), add(3)(p24),der(3)t(3;9)(p24;q12), add(4)(q32), $\operatorname{der}(4) \mathrm{i}(4)(\mathrm{q} 10) \operatorname{add}(4)(\mathrm{q} 35),+\mathrm{i}(4)(\mathrm{q} 10),-5, \operatorname{add}(6)(\mathrm{q} 16) \operatorname{del}(6)(\mathrm{p} 23),+\operatorname{add}(6)(\mathrm{q} 27),+\operatorname{add}(7)(\mathrm{p} 11)$, $-9,-10,-11, \operatorname{add}(11)(\mathrm{q} 23),+12,+\operatorname{add}(12)(\mathrm{p} 11),-13,+14,+15, \operatorname{add}(16)(\mathrm{q} 21),-17,-18,-18,-20$, $+21,+\operatorname{add}(21)(\mathrm{p} 12),+\operatorname{mar} 1,+\operatorname{mar} 2,+\operatorname{mar} 3,+\operatorname{mar} 4,+1-6 \operatorname{mar}[\mathrm{cp} 10]$

69-71,XX,-Y,+der $(X) t(X ; 14)(q 22 ; q 11),+2,+\operatorname{der}(3) t(1 ; 3)(q 11 q 27),+\operatorname{der}(4) t(4 ; 12 ; ? ; 15)(q 21$; q15q22;?;q13),-5,der(5)t(5;?;16)(p15.3;?;q11),+der(7)t(7;?;10)(q11.2;?;q11), +8, +8, add(9)(p22), -11 , add(11)(p15), add(12)(p13), add(12)(p13), $+\operatorname{der}(12) t(12 ; ? ; 15)(q 22 ; ? ; q 13),-13,-14,-15$, -16,-17, der (17)t(7;?;17)(p13;?;q25),-18, der(20)t(14;20)(q11;p11),+21, +21, +22 [cp5]/69-71, idem, $-1,+\operatorname{add}(1)(q 32),-8,+i(8)(q 10)[c p 4]$

62-64,XY, $-\mathrm{X},+\operatorname{del}(1)(\mathrm{p} 34),-4,-5, \operatorname{add}(5)(\mathrm{q} 35),+\operatorname{del}(6)(\mathrm{q} 21),+8,-9,-10,-11,+\mathrm{i}(12)(\mathrm{p} 10),-13$, $-17,-18,-22,+0-5 \operatorname{mar}[\mathrm{cp} 2]$

$52-56, X X Y, \operatorname{add}(1)(q 11),+\operatorname{der}(1) t(1 ; 2)(q 10 ; p 10),-2, \operatorname{add}(3)(p 12),-4,-5,-6, \mathrm{i}(7)(p 10),-9, \operatorname{del}(9)$ $(q 11),-10,-11, \operatorname{der}(11) t(9 ; 11 ; 11)(q 13 ; q 13 q 25 ; q 25),-13, \operatorname{add}(13)(q 21),+\operatorname{add}(14)(p 12),-15,-16$, $-18,-19,-20,-21,-21,-21,-22,-22,+\operatorname{mar} 1,+\operatorname{mar} 2,+1-4 \operatorname{mar}[\mathrm{cp} 10]$

68-74,XXY,tas $(1 ; 9)(\mathrm{p} 36 ; \mathrm{q} 34), \operatorname{del}(6)(\mathrm{q} 13 \mathrm{q} 14),+8,-9, \operatorname{tas}(9 ; 17)(\mathrm{q} 34 ; \mathrm{q} 25)+\mathrm{i}(12)(\mathrm{p} 10) \times \underline{2},+14,-17$, $-18, \operatorname{add}(18)(\mathrm{p} 11.3),-22,+0-3 \operatorname{mar}[\mathrm{cp} 10]$

64-66,XX, $-Y$, add(1)(p32), add(1)(q31), +add(3)(p14), -5, +7,-10,-11, +add(12)(q11), $? \mathrm{i}(12)(\mathrm{p} 10) \times 2,-13,-14, \operatorname{add}(15)(\mathrm{q} 24),-19,20,-21,-22,+3-6 \operatorname{mar}$ [cp4]

53-61,X,add(X) (q11), Y, add(1)(p36),-2, $\operatorname{add}(3)(\mathrm{p} 21),-4,-5,-6, \operatorname{add}(9)(\mathrm{q} 21),-10,-11,+\mathrm{i}(12)(\mathrm{p} 10)$, $-13,-15,-18,-19,-21,-22,-22,+\operatorname{der}(?) t(7 ; ? ; 12)(\mathrm{p} 11 ; ? ; \mathrm{p} 11),+\operatorname{mar} 1,+\operatorname{mar} 2,+3-12 \operatorname{mar}[\mathrm{cp} 8]$

$61-67, X X,-Y,-4,+7,-9,-10,-11$, add(11)(q13), $+\mathrm{i}(12) \operatorname{ip} 10) \times 2,-13,-14,-18$, add(19)(q13), +add $(19)(\mathrm{q} 13),-22,+\operatorname{mar} 1[\mathrm{cp} 8]$

56-61, XXY,add(1)(p21),-4,-5,ins(5;?)(q11;?), add(6)(q24), +8,-9,-9,-9,-10,-11,-11,-13,-14, $\operatorname{add}(14)(\mathrm{p} 12), \operatorname{der}(16) t(9 ; 16)(\mathrm{p} 21 ; \mathrm{p} 12),-18,-22,+\operatorname{der}(?) t(? ; 7)(? ; \mathrm{p} 13), \pm \operatorname{der}(?)(11 ; ? ; 12)(\mathrm{q} 12.1 ; ? ; \mathrm{p} 11)$ $+\operatorname{mar} 1,+0-1$ mar $[\mathrm{cp} 10]$

$60-64, \mathrm{XX},-\mathrm{Y},-3,-4,-5, \operatorname{add}(6)(\mathrm{p} 22),+\operatorname{add}(7)(\mathrm{q} 22), \operatorname{der}(8) \mathrm{t}(8 ; 12)(\mathrm{p} 11.2 ; \mathrm{p} 11,2),-9,-11, \operatorname{add}(11)$ (p12), add(12)(p12),-13,-14,-16,-17,-18,+21,+21,+mar1,+mar2,+mar3,+0-1mar[cp7]/ 60-62, $\operatorname{der}(X) t(X ; 1)(\mathrm{q} 21 ; q 12),-Y, \operatorname{add}(3)(p 24),-4,-5,-6,+\mathrm{i}(8)(q 10),-9,-9,-11,-11,+\operatorname{add}(12)$ $(q 14),-13,-16,-17,-17,-18, \operatorname{add}(20)(q 12),+21,+22,+r,+\operatorname{mar} 1,+0-3 \operatorname{mar}[\mathrm{cp} 3]$

66-67,X,add(X)(q28), -Y,add(1)(q11), add(1)(q43),+2,-4,-5, add(5)(p15), -6,-6,ins(6;?)(q11;?), $+7,+8,-9, \operatorname{idic}(9)(\mathrm{p} 24),-11,+12,-13,+15, \operatorname{dic}(17 ; ? ; 21)(\mathrm{p} 11.2 ; ? ; \mathrm{p} 12),+\operatorname{der}(21) \mathrm{t}(6 ; 21)(\mathrm{p} 11 ; \mathrm{p} 12)$, $\operatorname{add}(22)(\mathrm{p} 12),+\operatorname{mar} 1[\mathrm{cp} 9]$

$210159-62, X X Y, \operatorname{del}(1)(\mathrm{p} 35),-2, \operatorname{add}(3)(\mathrm{p} 12),-4,-5,+\operatorname{del}(8)(\mathrm{p} 11),-9,-10, \operatorname{add}(10)(\mathrm{q} 22),-11,-13,-14$, $-15,-18,-19, \operatorname{der}(20) \mathrm{t}(12 ; 20)(\mathrm{p} 11 ; \mathrm{p} 11),+21,-22,+\operatorname{mar} 1,+\operatorname{mar} 2[\mathrm{cp} 10]$

$57-64, \mathrm{XXY},+\mathrm{Y}, \operatorname{add}(2)(\mathrm{q} 24), \mathrm{t}(3 ; 15)(\mathrm{p} 23 ; \mathrm{q} 24),-4, \operatorname{dic}(4 ; 11)(\mathrm{p} 16 ; \mathrm{p} 11.2),-5$, add(6)(q13), $+8,-9,-10$, $-11,-11, \mathrm{i}(12)(\mathrm{p} 10),+\mathrm{i}(12)(\mathrm{p} 10),-13,-14,-15,-15,-16,-18, \operatorname{add}(19)(\mathrm{q} 13.1),+\operatorname{der}(21) \mathrm{t}(12 ; 21)$ (p11;p11), + mar1, +mar2,+mar3,+mar4,+0-2mar [cp7]/62-63,idem, +add(4)(p16),+11[cp3] arms (if involving more that $50 \%$ of its length and accounting for only the long arms of acrocentric chromosomes as described by De Jong et al. [3]) for each chromosome was determined. These data, depicted in Figure 1, indicate a similar pattern of chromosomal over- and underrepresen- tation in SE and NS, i.e., underrepresentation of (parts of) chromosomes $4,5,9,11,13$, and 18 , and overrepresentation of (parts of) chromosomes 7, 8, 12, and X.

The aberrations found by CGH are illustrated in Table 2 and Figure 2 (only the results obtained from analysis of SE 

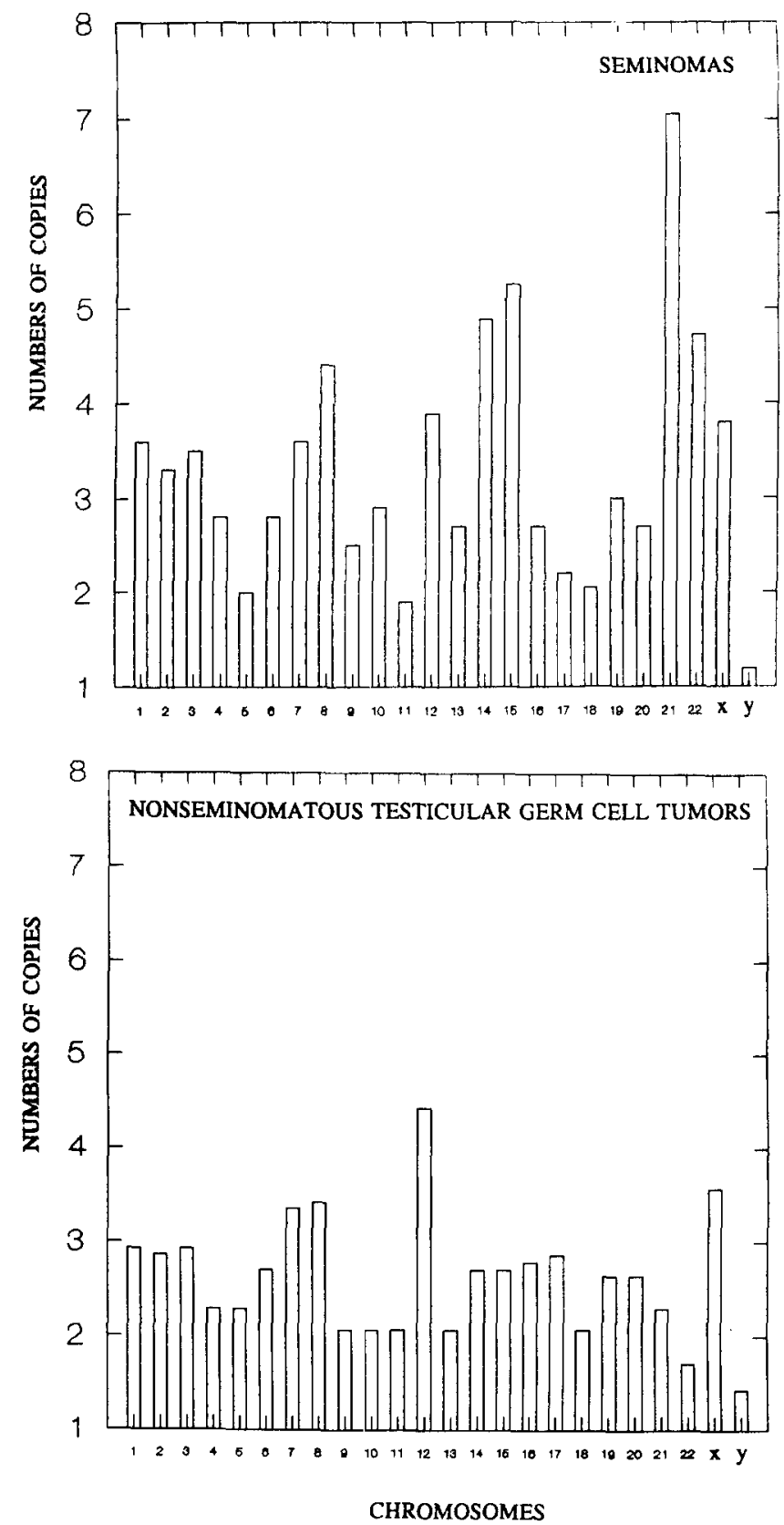

Figure 1 Schematic representation of the average copy number per chromosome for six seminomas and seven nonseminomatous testicular germ cell tumors of adolescents and adults, calculated on the basis of karyotypic results as reported before [3].

with instrument settings assuming $50 \%$ host cells are shown). Those aberrations that were also detected (partly) with karyotyping are unclerlined in Table 1 . Within the group of the six primary $\mathrm{SE}$, gain was found 14 times involving six different chromosomes, and loss six times involving three different chromosomes. For the NS ( $n=7$ ), gain was found 10 times affecting four different chromosomes and loss five times affecting four different chromosomes. No imbalances were detected by CGH for chromosomes 1 , $16,17,20,21,22$, and $Y$ (these are excluded from Figure 2), whereas aberrations (of parts) of chromosomes 2, 5, 9,
18 , and 19 were only found in a single primary tumor. The following regions showed aberrations in multiple cases: loss of parts of chromosome 4 (in one SE, one NS, and one SE of a CT), 11 (in one NS and a SE of a CT), and 13 (in three SE, one NS, and one SE of a CT), gain of parts of chromosome 7 (in three SE, one NS, and one NS of a CT), 8 (in three SE, one NS, and one NS of a CT), complete 12p (in three SE, six NS, and one NS of a CT), region 12p11.1p12.1 (in one NS and both components of one CT) and X (in three SE and one NS). Some aberrations found in SE were only identified using the instrument settings assuming $50 \%$ tumor, i.e., loss of 13q31-qter in tumor 4255 and 13 in tumor 2655 , and gain of 8qter in tumor $1665,7 q 11$ in tumor 5718 , and $7, \mathrm{X}$ in tumor 5731.

Although only the SE components of the CTs could be karyotyped (Table 1), both histological components were studied by CGH (Table 2). Gain of 12p11.1-p12.1 was detected in both components of tumor 2207 (illustrated in Figure 3). The ratio value of the amplicon was approximately three times higher in the SE compared to the NS (not shown). Other aberrations were found either in the SE or NS component within that CT. The other CT (3284) showed only gain of $12 \mathrm{p}$ in the NS component by CGH. The residual tumors showed four times gain, affected two different chromosomes, and five times loss affecting four different chromosomes. Both cases showed loss of part of the long arm of chromosome 6 (encompassing q15-q21) and gain of the complete short arm of chromosome 12 .

Although most aberrations found by CGH were confirmed by karyotyping, others were unexpected, i.e., overrepresentation of region $9 \mathrm{q} 21-\mathrm{q} 31$ in $4255,8 \mathrm{q} 11.1-\mathrm{q} 12$, and 12p11.1-p12.1 in 3035.

\section{DISCUSSION}

The series of six SE and seven NS presented here, shows a pattern of over- and underrepresentation of (parts) of chromosomes as found in a group of more than 100 TGCTs published before [5]. The recently developed technique of comparative genomic hybridization (CGH), a bicolor FISHapproach that enables detection of relative over- and underrepresentation of chromosomal regions [14], turned out to be very useful in the detection and mapping of DNA-sequence copy number changes in solid tumors [12, 14, 21-23, 27-35]. We applied this technique to a series of karyotyped TGCTs to screen for chromosomal regions showing imbalances in these tumors possibly unidentified by conventional chromosomal analysis.

Multiple cases showed gain of (parts of) chromosome 7 , $8, \mathrm{X}$, and the short arm of chromosome 12, and loss of (parts of) chromosome 13 both by karyotyping and CGH. Although other losses or gains of some chromosomal regions were expected from karyotypic analysis, these were not detected by CGH. This may be partly due to the presence of chromosomal segments hidden in markers, tumor heterogeneity, the sensitivity of the CGH applied, as well as the presence of host cells in the samples (illustrated by the results in SE). However, some unexpected copy number changes were detected by CGH in our series of TGCTs. These changes mostly involved small chromosomal re- 
Table 2 Gains and losses of chromosomal regions in testicular germ cell tumors of adolescents and adults detected by comparative genomic hybridization

\begin{tabular}{|c|c|c|c|}
\hline Histology & Case & Loss & Gains \\
\hline \multicolumn{4}{|l|}{ Seminoma } \\
\hline & 4255 & 13q31-qter & $8,9 q 21-q 32$ \\
\hline & 1665 & & $8 q t e r, 12 p$ \\
\hline & 5718 & & $12 \mathrm{p}, \mathrm{x}, 7 \mathrm{q} 11$ \\
\hline & 5731 & 13 & $7,8 \mathrm{q}, \mathrm{X}$ \\
\hline & 7214 & $4 p, 4 q 13-q$ ter & $4 q 12$ \\
\hline & 2655 & 13,18 & $7 q 11,12 p, X$ \\
\hline \multicolumn{4}{|c|}{ Nonseminoma } \\
\hline & 239 & & $12 \mathrm{p}$ \\
\hline & 3035 & & $7 p, 8 q 10-q 12,12 p 11.1-p 12.1$ \\
\hline & $\mathbf{5 1 1 6}$ & & $12 \mathrm{p}$ \\
\hline & 6537 & 19 & $12 \mathrm{p}$ \\
\hline & 8007 & & $12 p$ \\
\hline & 1862 & $4 q, 11 q 22-q$ ter & $12 \mathrm{p}$ \\
\hline & 2871 & 13 & $12 \mathrm{p}, \mathrm{X}$ \\
\hline \multicolumn{4}{|c|}{ Combined tumors } \\
\hline \multicolumn{4}{|c|}{ Seminoma } \\
\hline & 2207 & $4 q, 13 q$ & $12 \mathrm{p} 11.1-\mathrm{p} 12.1$ \\
\hline & 3284 & 11q13-qter & 2q35-qter, 6p10-p21.2 \\
\hline \multicolumn{4}{|c|}{ Nonseminoma } \\
\hline & 2207 & & $7 \mathrm{q} 11-\mathrm{q} 21,8 \mathrm{q} 21-\mathrm{q} 23,12 \mathrm{p} 11.1-\mathrm{p} 12.1$ \\
\hline & 3284 & & $12 \mathrm{p}$ \\
\hline \multicolumn{4}{|c|}{ Residual tumors } \\
\hline & 2101 & $6 q 15-q 21$ & $12 p$ \\
\hline & 5695 & $5,6 q, 12 q 21-q 22,13 q$ & $8 p, 12 p$ \\
\hline
\end{tabular}

gions not detected with conventional karyotyping. In addition, CGH enabled us to determine the minimal regions of overlap of parts of chromosomes showing imbalances, i.e., $7 q 11$ and 13q31-qter. These results are in line with CGH data of a paraffin embedded SE obtained after universal DNA amplification [36]. Consistent with karyotypic analysis of a large series of TGCTs ([5] and this paper), overrepresentation of $12 p$ is the most frequent aberration found. Interestingly, CGH revealed in two $\mathrm{i}(12 \mathrm{p})$-negative tumors (one SE and both components of a CT) specific amplification of a subregion of the short arm of chromosome 12 , i.e., 12p11.1-p12.1. Although this same region was recently found to be amplified in a metastasis of a testicular SE [12], we now report that this anomaly may also be encountered in primary TGCTs. A very similar observation was recently made in three additional primary TGCTs (M. Korn, personal communication).

Because karyotyping of both the SE and NS components of CTs is hard to achieve, CGH was used to compare their chromosomal constitutions. The results obtained illustrate that the SE and NS components of both cases studied here were at least partially genetically distinct. The only common aberration was the amplification of 12p11.1p12.1 in both components of one CT. However, the ratio value in the SE was approximately three times higher than in the NS. As we recently suggested [37] these results indicate the SE and NS components of CTs might be monoclonal or biclonal in origin.
Figure 2 Schematic representation of relative loss (indicated on the left side of the chromosome) and gain (indicated on the right side of the chromosome) of chromosomal regions, detected by comparative genomic hybridization in six seminomas (marked by lines), seven nonseminomatous testicular germ cell tumors of adolescents and adults (marked by dotted lines), both components of the combined tumors (illustrated as the pure SE and NS), and two metastatic residual tumors (also indicated by dotted lines).

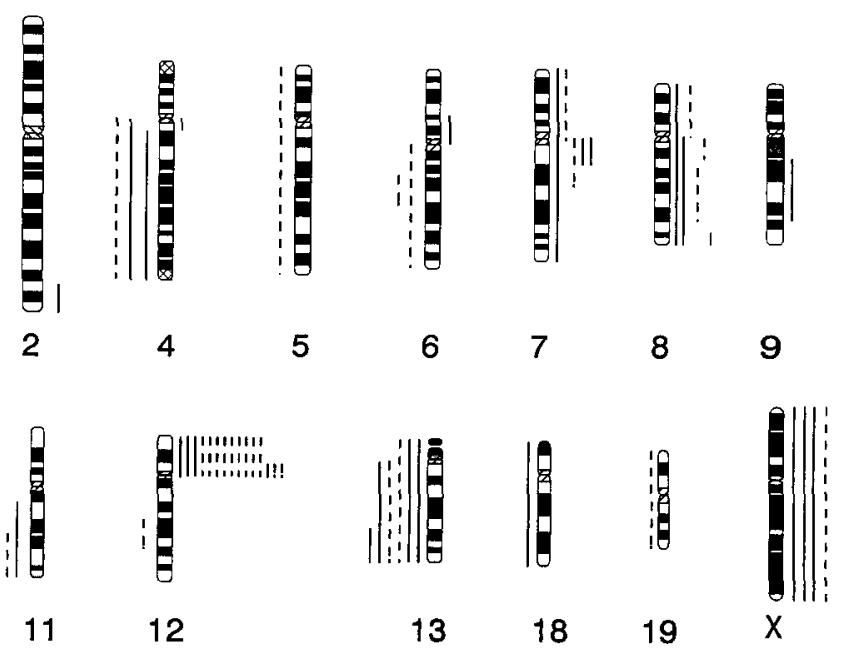



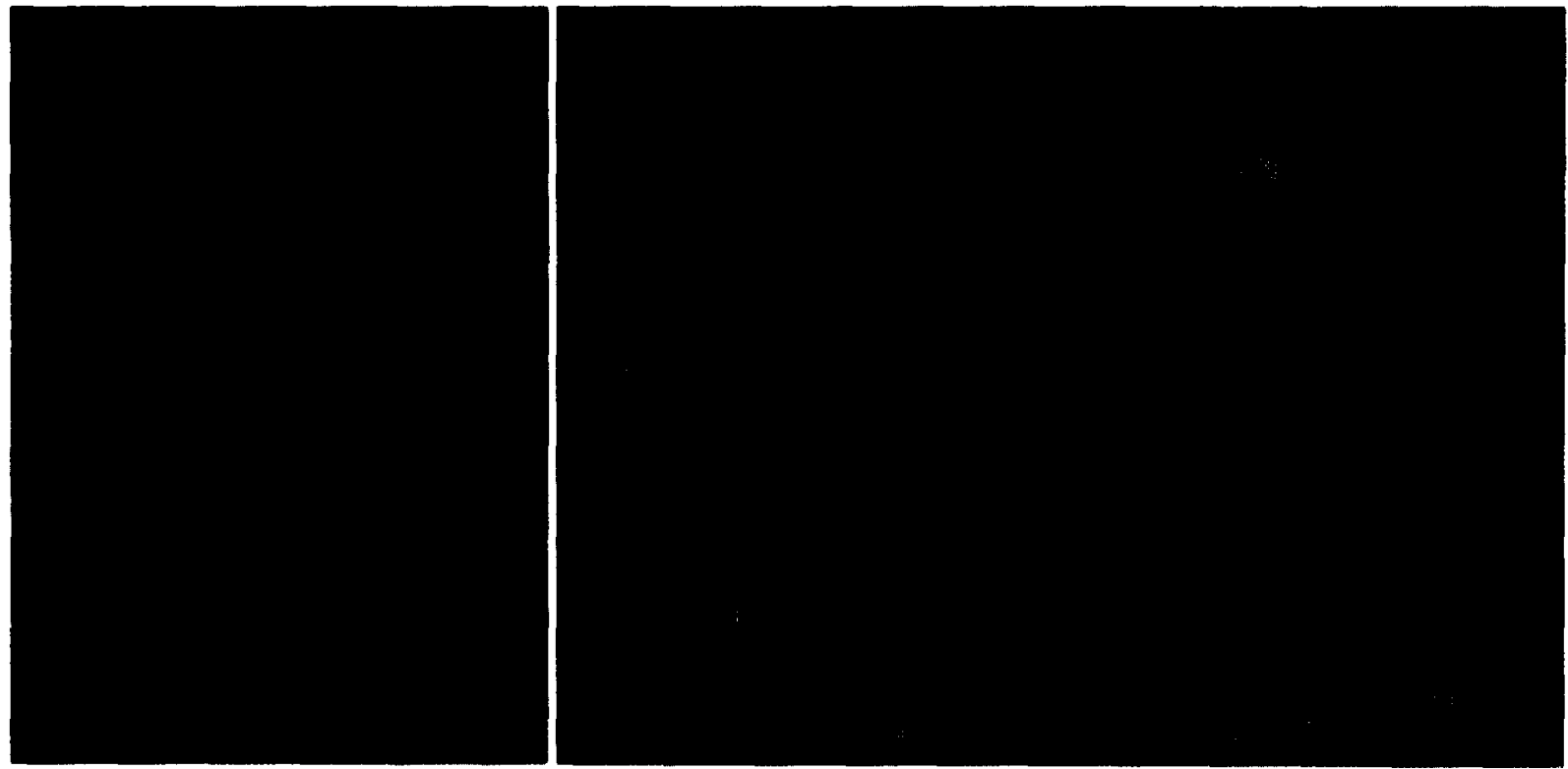

Figure 3 Example of the result of comparative genomic hybridization on chromosome 12 of the seminoma component of combined tumor 2207, showing tumor specific amplification (represented as relative overrepresentation of the green compared to the red signal), encompassing region 12p11.1-p12.1. The blue line represents the ratio profile, i.e., the red to green fluorescence intensities over the whole chromosome length.

Another interesting finding with CGH is the specific loss of 6q-sequences (involving q15-q21) in both residual tumors. This suggests that loss of gene(s) localized in this region may be involved in resistance to chemotherapeutic treatment, as recently suggested for glioblastoma multiforme [38]. Obviously, more data are required to substantiate this notion.

In conclusion, our study of CGH on a limited number of TGCTs largely confirms our karyotypic findings on a series of more than 100 tumors [5]: overrepresentation of (parts of) chromosomes $7,8,12$, and $\mathrm{X}$, and underrepresentation of chromosome 13. In addition, through CGH the most likely regions involved could be identified, i.e., 7q11 and 13q31-qter. The most intriguing finding, however, is the amplification of a restricted region of the short arm of chromosome 12, 12p11.1-p12.1, in different primary TGCTs, Analysis of more TGCTs using this approach will bring the isolation of the relevant gene(s) on $12 p$ in the realm of feasibility.

We thank G. te Meerman and B. de Jong of the Medical Genetics Department of the University of Groningen for their assistance and advice. We also would like to acknowledge the clinicians involved in the collection of the patient material. This work was supported by the Dutch Cancer Society (Koningin Wilhelmina Fonds) grant DDHK 94-836.

\section{REFERENCES}

1. Swerdlow AJ (1993): The epidemiology of testicular cancer. Eur Urol 23:35-38.

2. Giwercman A, Von der Maase H, Berthelsen JG, Rorth M, Bertelsen A, Skakkebaek NE (1991): Localized irradiation of testes with carcinoma in situ: Effects on Leydig cell function and eradication of malignant germ cells in 20 patients. J Clin Endocr Metabol 73:596-603.

3. De Jong B, Oosterhuis JW, Castedo SMMJ, Vos A, Te Meerman G) (1990): Pathogenesis of adult testicular germ cell tumors: A cytogenetic model. Cancer Genet Cytogenet 48:143-167.

4. Rodriquez E, Mathew S, Reuter V, Ilson DH, Bosl GJ, Chaganti RSK (1993): Cytogenetic analysis of 124 prospectively ascertained male germ cell tumors. Cancer Res 52:2285-2291.

5. van Echten J, Oosterhuis JW, Looijenga LHJ, Wiersma J, te Meerman G, Schraffordt Koops H, Sleijfer DTh, De Jong B (1995): No recurrent structural abnormalities in germ cell tumors of the adult testis apart from i(12p). Genes Chrom Cancer 14:133-144.

6. Oosterhuis JW, Castedo SMMJ, De Jong B, Cornelisse CJ, Dam A, Sleijfer DT, Schraffordt Koops H (1989): Ploidy of primary germ cell tumors of the testis. Pathogenetic and clinical relevance. Lab Invest 60:14-20.

7. El-Naggar AK, Ro JY, McLemore D, Ayala AG, Batsakis JG (1992): DNA ploidy in testicular germ cell neoplasms: Histogenetic and clinical implications. Am J Surg Pathol 16:611618.

8. Atkin NB, Baker MC (1983): i(12p): Specific chromosomal marker in seminoma and malignant teratoma of the testis? Cancer Genet Cytogenet 10:199-204.

9. Mostofi FK, Sesterhenn IA, Davis CJJ (1987): Immunopathology of germ cell tumors of the testis. Sem Diagn Pathol $4: 320-341$.

10. Oosterhuis JW, Looijenga LHJ (1993): The biology of human germ cell tumours: Retrospective speculations and new prospectives. Eur Urol 23:245-250.

11. Suijkerbuijk RF, Sinke RJ, Meloni AM, Parrington JM, van Echten J, De Jong G, Oosterhuis JW, Sandberg AA, Geurts van Kessel A (1993): Overrepresentation of chromosome 12p sequences and karyotypic evolution in i(12p)-negative testicular germ-cell tumors revealed by fluorescence in situ hybridization. Cancer Genet Cytogenet 70:85-93. 
12. Suijkerbuijk RF, Sinke RJ, Olde Weghuis DEM, Roque L, Forus A, Stellink F, Siepman A, Van de Kaa C, Soares J, Geurts van Kessel A (1994): Amplification of chromosome subregion 12p11.2-p12.1 in a metastatis of an $\mathrm{i}(12 \mathrm{p})$-negative seminoma: Relationship to tumor progression? Cancer Genet Cytogenet 78:145-152.

13. Rodriquez E, Mathew S, Mukherjee AB, Reuter VE, Bosl GJ, Chaganti RSK (1992): Analysis of chromosome 12 aneuploidy in interphase cells from male germ cell tumors by fluorescence in situ hybridization. Genes Chrom Cancer 5:2129.

14. Kallioniemi A, Kallioniemi OP, Sudar D, Rutovitz D, Gray JW, Pinkel D (1992): Comparative genomic hybridization for molecular cytogenetic analysis of solid tumors. Science 258:818-820.

15. Pugh RCB (1976): Combined tumours. In: Pathology of the testis, RCB Pugh, ed. Blackwell, Oxford, pp. 245-258.

16. Castedo SMMJ, De Jong B, Oosterhuis JW, Seruca R, Te Meerman GJ, Dam A, Schraffordt Koops H (1989): Cytogenetic analysis of ten human seminomas (two of them lacking the i(12p)). Cancer Res 49:439-443.

17. Castedo SMMJ, De Jong B, Oosterhuis JW, Seruca R, Idenburg VJS, Dam A, Te Meerman GJ, Schraffordt Koops H, Sleijfer DT (1989): Chromosomal changes in human primary testicular nonseminomatous germ cell tumors. Cancer Res 49:56965701.

18. Wang HC, Fedoroff $S$ (1972): Banding in human chromosomes treated with trypsin. Nature 235:52-54.

19. Mitelman F (1991): Guidelines for Cancer Cytogenetics. Supplement to: An international system for human cytogenetic nomenclature. Karger, Basel.

20. Maniatis T, Fritsch EF, Sambrook J (1982): Isolation of high molecular-weight, eukaryotic DNA from cells grown in tissue culture. In: Molecular Cloning, Cold Spring Harbor Laboratory, New York, pp. 280.

21. Suijkerbuijk RF, Olde Weghuis DEM, Van den Berg M, Pedeutour F, Forus A, Mykleborst O, Glier C, Turc-Carel C, Geurts van Kessel A (1994): Comparative genomic hybridization as a tool to define two distinct chromosome 12-derived amplification units in well-differentiated liposarcomas. Genes Chrom Cancer 9:292-295.

22. Forus A, Olde Weghuis D, Smeets D, Fodstad O, Myklebost $O$, Geurts van Kessel A (1995): Comparative genomic hybridization of human sarcomas: I. Occurrence of genomic imbalances and identification of a novel major amplicon at 1q21q22 in soft tissue sarcomas. Genes Chrom Cancer 14:8-14.

23. Forus A, Olde Weghuis D, Smeets D, Fodstad O, Myklebost O, Geurts van Kessel A (1995): Comparative genomic hybridization analysis of human sarcomas: II. Identification of novel amplicons at $6 p$ and $17 p$ in osteosarcomas. Genes Chrom Cancer 14:15-21.

24. Trask BJ (1991): Fluorescence in situ hybridization: Applications in cytogenetics and gene mapping. Trends Genet 7:149154.

25. Du Manoir S, Schrock E, Bentz M, Speicher MR, Joos S, Ried T, Lichter P, Cremenr T (1995): Quantitative analysis of comparative genomic hybridization. Cytometry 19:27-41.

26. Kallioniemi OP, Kallioniemi A, Piper J, Isola J, Waldman FM,
Gray JW, Pinkel D (1994): Optimizing comparative genomic hybridization for analysis of DNA sequence copy number changes in solid tumors. Genes Chrom Cancer 10:231-243.

27. Levin NA, Brzoska P, Gupta N, Minna JD, Gray JW, Christman MF (1994): Identification of frequent novel genetic alterations in small cell lung carcinoma. Cancer Res 54:50865091.

28. Gordon KB, Thompson CT, Char DH, O'Brien IM, Kroll S, Ghazvini S, Gray JW (1994): Comparative genomic hybridization in the detection of DNA copy number abnormalities in uveal melanoma. Cancer Res 54:4764-4768.

29. Schrock E, Thiel G, Lozanova T, Du Manoir S, Meffert MC, Jauch A, Speicher MR, Nurnberg P, Vogel S, Janisch W (1994): Comparative genomic hybridization of human malignant gliomas reveals multiple amplification sites and nonrandom chromosomal gains and losses. Am J Pathol 144: 1203-1218.

30. Tarkannen M, Karhu R, Kallioniemi A, Elomaa I, Kivioja AH, Nevalainen J, Bohling T, Karaharju E, Hyytinen E, Knuutila S, Kallioniemi OP (1995): Gains and losses of DNA sequences in osteosarcomas by comparative genomic hybridization. Cancer Res 55:1334-1338.

31. Spleicher MR, Prescher G, Du Manoir S, Jauch A, Horsthemke B, Bornfeld N, Becher R, Cremer T (1994): Chromosomal gains and losses in uveal melanomas detected by comparative genomic hybridization. Cancer Res 54:38173823.

32. Ried T, Petersen I, Holtgreve-Grez H, Speicher MR, Schrock E, Du Manoir S, Cremer T (1994): Mapping of multiple DNA gains and losses in primary small cell lung carcinomas by comparative genomic hybridization. Cancer Res 54:1801-1806.

33. Kallioniemi A, Kallioniemi OP, Piper J, Tanner M, Stokke T, Chen L, Smith HS, Pinkel D, Gray JW, Waldman FM (1994): Detection and mapping of amplified DNA sequences in breast cancer by comparative genomic hybridization. Proc Natl Acad Sci USA 91:2156-2160.

34. Speicher MR, Howe C, Crottey P, Du Manoir S, Costa J, Ward DC (1995): Comparative genomic hybridization detects novel deletions and amplifications in head and neck squamous cell carcinomas. Cancer Res 55:1010-1013.

35. Voorter C, Joos S, Bringuier P-P, Vallinga M, Poddighe P, Schalken J, Du Manoir S, Ramaekers F, Lichter P, Hopman A (1995): Detection of chromosomal imbalances in transitional cell carcinoma of the bladder by comparative genomic hybridization. Am J Pathol 146:1341-1354.

36. Speicher MR, Jauch A, Walt H, Du Manoir $S$, Ried T, Jochum W, Sulser T, Cremer T (1995): Correlation of microscopic phenotype with genotype in a formalin-fixed, paraffin embedded testicular germ cell tumor with universal DNA amplification, comparative genomic hybridization, and interphase cytogenetics. Am J Pathol 146:1332-1340.

37. Gillis AJM, Looijenga LHJ, De Jong B, Oosterhuis JW (1994): Clonality of combined testicular germ cell tumor of adults. Lab Invest 71:874-878.

38. Kim DH, Mohapatra G, Bollen A, Waldman FM, Feuerstein BG (1995): Chromosomal abnormalities in glioblastoma multiforme tumors and glioma cell lines detected by comparative genomic hybridization. Int J Cancer 60:812-819. 